\title{
FORMATION OF PROFESSIONAL AND LEGAL COMPETENCE IN FUTURE SOCIAL WORKERS
}

\author{
Kovalchuk Vasyl ${ }^{1}$ \\ Zhuravska Nina ${ }^{2}$ \\ Yashchuk Sergii ${ }^{3}$
}

DOI: https://doi.org/10.30525/978-9934-571-78-7_20

Abstract. The analysed the extent of previous research of the issue of professional and legal competence formation of prospective social workers, defined the essence, and determined the structure of this pedagogical category. It is pointed out that professional and legal culture of the prospective social worker implies a profound knowledge of laws and regulations, sources of law which he/she should rely on in the working environment. The bases for implementing social policy in Ukraine are the following principles, such as social justice, social solidarity, individual social responsibility, social partnership. The professional competence of the future social worker is considered by us as an integral entity, which implies the presence of a combination of legal knowledge, abilities and skills as well as personalityimportant qualities that ensure the success of social work on a legal basis. Under legal knowledge, understand the student's knowledge of the legal and regulatory framework. The presence of legal skills implies the ability of the future social worker to apply the legal framework in the practice of social work. We have developed the structure of the professional competence of future social workers (knowledge, skills, skills in the legal area, legal consciousness, personality-important qualities) contains the following components: motivational-value, cognitive, practical-activity, personreflexive components. To assess the state of establishing the professional competence of future social workers, we have identified and characterized the

\footnotetext{
${ }^{1}$ Dr.hab. in Pedagogics, Professor, Head of the Department of Professional Education and Technologies of Agricultural Production, Oleksandr Dovzhenko Hlukhiv National Pedagogical University, Ukraine

${ }^{2}$ Doctor of Pedagogical Sciences, Professor at the Department

of Training Methodology and Management of Educational Establishments,

National University of Life and Environmental Sciences of Ukraine, Ukraine

${ }^{3} \mathrm{PhD}$ in Pedagogies,

Station of the Social School, Bordo France
} 
relevant levels (high (reflexive-creative), sufficient (functional), satisfactory (reproductive), low (empirically intuitive)). These levels are highlighted in accordance with the structure of the professional competence of future social workers. Let us present their content loading. For the effective formation of professional competence in future social workers in the conditions of the institution of higher education, it is necessary to create pedagogical conditions. We distinguish the following: the creation of positive motivation and the need for self-education and self-improvement. introduction of knowledge system about the essence and importance of professional competence to the content of their professional training; realization in the educational process of institutions of higher education of the expedient complex of traditional and innovative forms and methods; ensuring the readiness of teachers to form the professional competence of future social workers.

\section{Introduction}

Modern social and economic conditions of state development are accompanied with constant changes in normative legal documents. Therefore, the necessity of legal education of the population is one of the priority directions of the state legal policy of Ukraine. The subject of our survey is aimed at the social sphere because it is the most vulnerable in society.

Today, the training of future social workers in higher education institutions should be aimed at building competencies demanded in the labor market. This aspect is covered in copyright works [1-6].

Modern university education is focused on the formation of a new generation of specialists who have deep fundamental and special knowledge and are able to work creatively and independently and, as N. Divinska states, «it is absolutely clear that the success and further development of the state will depend on the quality of graduates' training» [7, p. 60].

English researcher Shulamit Ramon insists that the basis of social work is the support of socially vulnerable people [8]. Nowadays, in many countries of Europe, there is no clear distinction between the names of the professions «social worker» and «social teacher», regardless of which institution that specialist graduated from and what certificate was received by him/her. The definition of the content of the concepts of «social pedagogy» and «social work» is dealt with by the European group IASSW (International Association of Schools of Social Work) [8], in the USA - the Association of Social Workers [8]. 
V. Bocharova and N. Pyliuk consider social work as «a personal service to help people», which relies not on any one but on a certain set of sciences and accumulated experience of practical sociocultural, legal, socio-psychological, medical-health, rehabilitation-therapeutic and other personality support [10, p. 150-157].

The priority task of social work is to return the «social client» to the ability to act independently under certain social conditions.

\section{Directions of social policy in Ukraine}

The main directions of social policy in Ukraine at the present stage of development are:

- policy in the area of incomes of the population, which provides for the establishment of social standards of living, living standard parameters, and ensuring wage growth;

- policy of employment and occupational safety, which provides for the legislative establishment of means of labor protection, types and forms of social insurance, ensuring full productive employment of the population, preventing unemployment;

- social protection, which provides for the definition and establishment of parameters for pensions and other types of social insurance, social assistance, social services, as well as social benefits and guarantees;

- demographic policy, which envisages stimulation of reproductive population growth, state assistance to the family, regulation of migration processes;

- policy of social sphere development: cultural, linguistic, religious, youth, recreational policy, health care, education, science, etc. [11].

The main tasks of the social policy of Ukraine for 2017-2020 are:

- guaranteeing the constitutional rights of citizens to work, social protection, education, health care, culture, housing;

- achieving a decent level of material well-being and living conditions of people;

- lowering the level of property stratification of the population, overcoming poverty;

- ensuring full productive employment, improving the quality and competitiveness of the workforce;

- orientation of state policy towards the family, provision of rights and social guarantees to families; 


\section{Chapter «Pedagogical sciences»}

- providing support for the most vulnerable sectors of the population;

- formation of a civil society, provision political stability and mutual understanding in it;

- development of spirituality, culture, moral principles, intellectual potential of the Ukrainian people;

- preservation and strengthening of demographic and labor resource country's potential; stabilization of the demographic structure of society;

- development of social infrastructure;

- strengthening the physical health of the nation;

- optimization of social structure of society; establishment of guarantees of equal opportunities for achieving the material, ecological and social wellbeing;

- lowering the unemployment rate and ensuring productive employment;

- ensuring the stability of the public system;

- development of a system of education, elucidation and dissemination of information on sustainable development issues [11].

The bases for implementing social policy in Ukraine are the following principles, such as social justice, social solidarity, individual social responsibility, social partnership [12, p. 13].

The regulatory framework for the social sphere has been created in Ukraine. Legislation is constantly being amended and supplemented, new legislative acts and regulatory documents are adopted, which provide legal bases for resolving various social problems. Ukraine has ratified a number of international and European conventions and declarations, which so far have not found their reflection in the norms of Ukrainian legislation. At the same time, it should be noted that in the conditions of strengthening decentralization of state administration, the system of ensuring social protection of the population at the regional level becomes the most sensitive to unpredictable changes. There is a contradiction between the availability of personnel and analytical potential and the lack of funds, effective organizational structures working in the field of social protection.

In this aspect the problem of preparing future social workers for the realization of professional tasks is of growing actuality. Particular attention is paid to the formation of professional legal competence. After all, the high school is intended to prepare future social workers not only as professionals, but also as highly moral people with the established legal consciousness and legal culture, which is manifested through a number of indicators: 
knowledge of the current legislation, first of all, the Constitution, the basic rights, freedoms and responsibilities of social clients; respect for the right, respect for the rights of others, faithful fulfillment of their duties, which envisages the rule of law; the desire to build their behavior in accordance with legal (judicial) norms. Such transformations require future social workers to be professionally qualified to respond instantly to changes in the social environment, to take non-standard professional decisions that attract potential employers' attention [12].

\section{The essence of the professional competence of a future social worker}

The professional competence of the future social worker is considered by us as an integral entity, which implies the presence of a combination of legal knowledge, abilities and skills as well as personality-important qualities that ensure the success of social work on a legal basis. Under legal knowledge, understand the student's knowledge of the legal and regulatory framework. The presence of legal skills implies the ability of the future social worker to apply the legal framework in the practice of social work [14, p. 39].

Professional competence includes:

- knowledge (legal framework, information sphere, bases of socially acceptable behavior, moral and legal norms);

- ability (to make one's own professional decisions, to predict all consequences of legal situations (as a manifestation of reflection), to defend one's own professional legal opinion; to choose rationally justified professional and legal behavior (to understand and correctly perceive the social and legal signal; to recognize the principles of the mechanisms of socio-legal management; to get rid of the professional legal fear of communication with social clients); to build partner legal and professional relations; to recognize the professional legal conflict situation the one in close proximity to it);

- qualities (professional legal responsibility, the desire to acquire new professional and legal knowledge, the ability to professional selfimprovement, self-development and self-actualization, a realistic view of the socio-legal situation in the realities of life, plasticity and psychological flexibility as the ability to successfully orient oneself and act in constantly changing conditions of social and legal reality) [14, p. 71].

Modern and future life not only actualizes the problem of human development, its professional establishment, but sets new requirements 
for him/her as a person and a professional: the need, as never before, to develop a person based on his/her abilities, his/her orientation; the need to form a professional capable of innovative thinking and functioning in the global living and professional space; the ratio in the professional training of fundamentalism and specialization [15].

It should be noted that modern reforms in higher education require such ways of organizing and increasing the effectiveness of educational activities that will promote the unceasing progression of students and provide a reorientation of learning from the imaginary accumulation of knowledge to genuine skill development [16].

The versatility of the content of the category «professional competence» is conditionally divided into two groups of factors, which are formed under the influence of external and internal, managed and unmanaged, factors: quality and skills $[17$, p. 43-48]. Let us note that social work at the macro level is realized through the system of institutions and organizations of social work in their vertical and horizontal sections, headed by the Ministry of Labor and Social Policy of Ukraine. The level of compliance with socially determined requirements determines the level of competence of a specialist. Professional training is a process that reflects scientifically and methodically grounded measures of institutions of higher education, aimed at forming a level of professional competence of a specialist, level of professionalism.

\section{The structure of the professional competence of future social workers}

We have developed the structure of the professional competence of future social workers (knowledge, skills, skills in the legal area, legal consciousness, personality-important qualities) contains the following components: motivational-value, cognitive, practical-activity, personreflexive components.

The motivational and value component of the professional competence of future social workers involves the strength and stability of motives and values of the individual; social intelligence, divergent thinking, creative search, planning one's own life scenario, knowledge of life crises, understanding social reality, choosing a specialty.

The cognitive component implies knowledge of future social workers, social representations, depth, completeness and strength of socio-legal, 
pedagogical-legal and psycho-legal knowledge, independence of their acquisition and assimilation.

The practical-activity component involves the absence of difficulties in organizing the legal process of future social workers; systematic formation of socio-legal, pedagogical-legal and psychological and legal skills, skills and the wealth of practical experience in solving complex professionallegal problems in the system of work «social worker-client».

Personality-reflexive component implies the development of empathy legal orientation; psychic self-regulation, sense management, psychosexual literacy, autonomy, understanding of social roles, ability to feel the nuances of a social situation, solving the problem situations, responsibility.

\section{The indicators of forming the professional competence of future social workers}

The foregoing statement allows us to determine the indicators of forming the professional competence of future social workers that are relevant to each component of its structure:

- indicators of the full formation of the motivational-value component of the professional competence of future social workers reflect the motives of his/her professional and legal behavior (aspirations, desires, manifestations); ability to professional-legal development (personal goals and aspirations);

- indicators of the full formation of the cognitive component of the professional-legal competence of future social workers represent his/her pedagogical, legal, psychological, sociological-legal knowledge, the way of their acquisition and assimilation;

- indicators of the full formation of the practical-activity component of the professional competence of future social workers highlight the possibility of preventing difficulties in organizing the process of professional social work of social workers; skills, abilities and practical experience in the social worker-client system;

- indicators of the formation of personality-reflexive component of professional competence of future social workers characterize his/her empathy and professional-legal orientation (communicative skills, mobility and skills of business communication in a foreign language, focus on vocational training disciplines); ability to self-examination and self-esteem, readiness to raise the level of professional-legal competence (self-awareness 
of one's own professional-legal activity, ability to analyze and assess one's own motives, knowledge, skills, abilities and personality gifts).

Qualitative content of any indicator was determined by its essence, represented through the components of the professional competence of future social workers, namely: motivational-value, cognitive, practicalactivity, person-reflexive. According to the components, the criteria are defined: orientational, informative, procedural, regulatory, as well as features that characterize each of the components we have identified:

- strength and stability of motives, the ability to professional development;

- depth, completeness and strength of socio-legal, pedagogical-legal and psychological-legal knowledge and independence of their acquisition and assimilation;

- ability to organize the process of professional and legal activity of future social workers; quality of establishing socio-legal, pedagogical-legal and psychological-legal skills, abilities and the availability of practical experience in solving complex professional-legal problems in the work of the system «social worker-client»;

- the development of the empathy of the professional-legal orientation of future social workers (the degree of development of communication, organization and focus on vocational training disciplines), the completeness and development of the ability of future social workers to critical introspection and self-esteem readiness to raise the level of professional competence.

\section{The levels the professional competence of future social workers}

To assess the state of establishing the professional competence of future social workers, we have identified and characterized the relevant levels (high (reflexive-creative), sufficient (functional), satisfactory (reproductive), low (empirically intuitive)). These levels are highlighted in accordance with the structure of the professional competence of future social workers. Let us present their content loading.

The high level (reflexive-creative) of the formation of the professional competence of future social workers is characterized by such features as: strong and stable motives of legal behavior (strong and stable aspirations, desires and manifestations); ability to professional development (personal goals and aspirations); deep, complete and strong socio-legal, pedagogicallegal and psychological-legal knowledge, independence of their acquisition and assimilation; the absence of difficulties in organizing the process of 
professional and legal activity of future social workers; full formation of socially-legal, pedagogical-legal and psychological-legal skills, abilities and availability of practical experience in solving complex professionallegal problems in the work of the system «social worker-client»; the ability to easily and successfully solve legal problems; the presence of painfully developed empathy; professional orientation of future social workers (excessive communicative ability and focus on vocational training disciplinesover- organization or bureaucratization); developed ability to critical introspection and self-esteem, readiness to increase professionallegal competence (complete self-awareness of professional-legal functions in the activities of a social worker, excellent ability to analyze and assess one's own motives, knowledge, abilities, skills and personality abilities, implemented without any help from colleagues).

Sufficient level (functional) - not steady motives of professional-legal behavior (certain aspirations, desires and manifestations); certain ability to professional development (certain personal goals and aspirations); in general, unsustainable socio-legal, pedagogical-legal and psychological-legal knowledge, their rather active acquisition and assimilation, in the presence of minor mistakes in their reproduction; the emergence of sometimes minor difficulties in organizing the process of professional and legal activity of future social workers; certain formation of socio-legal, pedagogical-legal and psychological-legal skills, abilities and sufficient practical experience in solving complex professional-legal problems in the system of work «social worker-client»; certain ability to solve socio-legal problems and tasks (certain ability to correctly predict professional and legal activity in a professional environment, to constructively solve professional-legal tasks in the activities of a social worker, but some difficulties are present); certain empathy; certain professional-legal orientation of future social workers (not stable communicative skills, organization, focus on professional disciplines); the presence of difficulties in carrying out self-examination and self-assessment of readiness to increase the level of professional-legal orientation (not stable self-awareness of professional-legal functions in the activities of a social worker, not able to analyze and assess one's own motives, knowledge, skills, abilities and personality abilities).

Satisfactory (reproductive) - periodically arising motives of social behavior (insignificant desire, periodic desire and their respective manifestations); insignificant ability to professional development (insignificant personal 
goals and aspirations); incomplete and fragile socio-legal, pedagogicallegal and psychological-legal knowledge, their acquisition and assimilation is carried out from time to time both independently and with the help of colleagues; characteristic of frequent errors during their reproduction; the periodic occurrence of difficulties of varying degrees of complexity in professional-legal activities; insignificant formation of socio-pedagogical and socio-psychological skills, abilities and little practical experience in solving complex professional-legal problems, but their rare use in practice; not always easy and correct solution of professional legal problems and tasks (it is not always easy to predict the professional-legal activity in the professional environment, to constructively solve the professional-legal tasks in professional activity, as well as the tasks of socialization, education and development of the person; to organize and manage the process of solving professional-legal problems in professional activity; organize professionallegal activity on a diagnostic basis; carry out pedagogical reflexing); moderately developed empathy; insignificant focus on professional discipline; the ability to critically analyze and self-assess the readiness for raising the level of professional-legal competence (weak self-awareness of professionallegal functions in pedagogical activity, ability to analyze and evaluate one's own motives, knowledge, abilities, skills and personal abilities that require periodic assistance of colleagues), is not fully developed.

Low level (empirically-intuitive) - weak motives of social behavior (almost no desire, weak desire and, accordingly, its infrequent manifestation); weak ability to professional-legal development (personal goals and aspirations are almost absent; surface and fragmentary sociolegal, pedagogical-legal and psychological-legal knowledge, their acquisition and assimilation is carried out very rarely and usually with the help of colleagues; frequent making significant errors; constant occurrence of significant difficulties in organizing the process of professional and legal activity of future social workers, the presence of poorly formed sociolegal, pedagogical-legal and psychological-legal skills, and small practical experience in solving complex professional-legal problems in the system of work «social worker-client», which is usually rarely used in practice, poorly developed empathy, poor professional-legal orientation of future social workers (weak communicative skills, organizational skills, there is almost no focus on professional discipline); practical inability to critique self-examination and self-assessment of readiness to increase the level 
of professional-legal orientation (professional-legal functions of a social worker are almost not realized, very weak quests to analyze and assess one's own motives, knowledge, skills, abilities and personality abilities, which requires significant assistance from colleagues [14, p. 76-82].

\section{Pedagogical conditions the effective formation of professional competence}

For the effective formation of professional competence in future social workers in the conditions of the institution of higher education, it is necessary to create pedagogical conditions. We distinguish the following: the creation of positive motivation and the need for self-education and selfimprovement. introduction of knowledge system about the essence and importance of professional competence to the content of their professional training; realization in the educational process of institutions of higher education of the expedient complex of traditional and innovative forms and methods; ensuring the readiness of teachers to form the professional competence of future social workers.

While substantiating the first pedagogical condition, it was emphasized that the creation of positive motivation in the educational process of EHE must be foreseen through a system of appropriate measures that would contribute to the formation of the need for self-education and self-improvement (S. Kalahur, L. Melnyk, O. Slobodyan and others), in particular: introduction of the system knowledge of the essence and significance of the professional competence of future social workers to the content of their professional training; implementation of a feasible set of traditional and innovative forms and methods that contribute to the formation of the professional competence of future social workers. In the context of the research, the author relies on the psychological concept of O. Kovalyov, according to which self-education is a conscious systematic work of the individual over himself/herself in order to eliminate the disadvantages and the formation of positive qualities due to the requirements of society and one's own development program.

Explaining the second pedagogical condition, it is emphasized that the system combines two types of knowledge: scientific-theoretical and practical (S. Honcharenko, V. Korneshchuk, P. Luzan, M. Sherman and others). Theoretical knowledge includes the knowledge about the structural components of professional competence, its level of formation depending 
on the successful acquisition of the profession of a social worker, awareness of the social role of the future specialist, perception of the professional requirements, conscious application of these requirements to himself/ herself, self-education of the necessary qualities, modeling the personality of social worker. The analysis of the academic disciplines provided for by the curricula of the specialty 231 «Social Work» I (Bachelor) level of higher education and the II (Master's) higher education level, revealed that the main blocks are combined be the disciplines of social work and psychology. Disciplines of other blocks (sociological, legal, and political) are limited by the circle of real necessity for the fulfillment of professional tasks. In the basis of the author's proposed socio-legal tasks for the formation of professional legal competence of future social workers for professional disciplines, educational (familiarization with the specialty, socio-pedagogical, sociopedagogical in the countryside) and production (socio-pedagogical, prediploma) practice I (Bachelor) level of higher education and II (Master's) higher education level, specialty 231 «Social work», is the realization of objective aspects, namely: development of contemporary society in Ukraine, in particular, rule of law and subjective aspects, namely: education, including vocational education and legal characteristics of observance of human rights, professional and legal consciousness of a social worker.

The actualization of the third pedagogical condition of our study is conditioned by the main provisions of the psychological and pedagogical thought (O. Leontiev, S. Rubinstein), that the activity itself is a universal form of the functioning of the individual and that the effective formation of the qualities of a person is possible only if it is included in various forms, and activities. It has been found out that there is a need for the implementation of a feasible set of traditional and innovative forms and methods, namely: problem-developing, training, game, design technology, elective «Professional-legal competence of a social worker», socio-legal problems, socio-legal projects, social and legal training, social and legal cases, etc., which stimulate the activity of future social workers, contribute to the formation of the need for self-improvement and self-education, improve the effectiveness of forming their professional-legal competence.

The definition of the fourth pedagogical condition of the research is conditioned by the conceptual provisions of the psychological and pedagogical science on the leading role of the teacher's personality in the educational process (K. Ushynskyi). It is indicated that the continuous 
valuation of indicators and the determination of the amount of points more objectively characterizes the level of readiness (L. Stepanenko). Implementation of the set of activities for the faculty provides the readiness of teachers to form the professional legal competence of future social workers, in particular, methodological recommendations for scientific and pedagogical workers «Development of professional legal competence of future social workers», course of lectures «Features of the methodology of social and pedagogical disciplines» and the content-methodical aspects of the elective and electronic course, based on the Moodle information environment, «Professional and Legal competence of a social worker» at a scientific and practical seminar on improving the teachers' teaching skills. Analysis of the literature of pedagogical direction, once again proves that there is a need in knowing foreign languages by teachers and the possession of information and communication technologies by them, in particular, the method of compiling e-courses [13, p. 6-8].

\section{The principles formation of professional competence}

Formation of professional competence is based on general and specific principles.

General are guiding provisions, normative requirements for organizing and conducting the didactic process, have «the character of general instructions, rules and norms and proceed from its natural laws» [18]. We agree with P. Pidkasystyi's conclusion [19], which generally acknowledges such general-didactic principles: consciousness and activity; visibility; systematic and consistent; durability; scientific knowledge; accessibility; interconnection of theory and practice. Let us dwell on the substantiation of the general and specific principles indicated in the model of the formation of professional competence.

Consequently, the principle of science is based on a clear link between the content of science and the disciplines of specialty 231 «Social Work». This principle is based on the current achievements of social, legal sciences and psycho-pedagogical innovations. It involves the development of a high level of creative search for professional social work among future social workers. The practical implementation of this principle requires the introduction of interactive forms of training for future social workers, and socio-legal tasks that contain elements of problem-solving. In applying this principle, we were training future social workers to be able to conduct a scientific discussion, 
with reasoned and convincing arguments: to scientifically substantiate the educational material in the legal field; to feel close connection and practical significance of the educational material for the future practical work of social workers in the legal plane; to reveal cause-effect relationships.

The principle of activity is based on the fact that through activity there is a conscious assimilation of knowledge, skills and abilities. Future social workers can think independently in the legal field, find an original approach to solving professional-legal tasks of different levels of complexity in their activities. The principle of activity involves the development of future social workers' desire to independently acquire knowledge for implementing future socially significant practical activities in solving the problems of «social clients» in a legal way. In active training, future social workers acquire the necessary knowledge, improve their skills and abilities for future professional activities and develop their own professional-legal abilities. Dialogue communication is used for development of their activity.

The principle of systematic and sequential learning assumes that knowledge, skills and abilities are formed systematically, in a definite manner, with each new material based on the previous material and interrelated with it. In accordance with this principle, the training material should be a clear logical chain in itself. This principle aims to fully understand the content and means of professional competence in the process of acquiring knowledge, skills and abilities by the future social worker. In the short term, it is impossible to fully and comprehensively acquaint with the algorithms for solving all possible socio-legal problems, so the future social worker should be aimed at conscious and independent mastering of the educational material of the professional legal content. We have taken into account the fact that future social workers deliberately used their acquired knowledge they needed for future real professional activities. This principle requires that training be built on the level of real opportunities and encourage future social workers to self-improvement.

The principle of visibility (visualization) implies that on the basis of demonstrating the professional legal events in the form of video films, schemes for solving the social and legal tasks, drawings, computer simulation, presentations (within the framework of an electronic course, lectures, practical works, optional seminars «Professional-legal culture of a social worker») future social workers have the opportunity to develop their professional competence. Visibility, as O. Pometun notes, performs the following functions: «promotes the mental development of subjects of 


\section{Kovalchuk Vasyl, Zhuravska Nina, Yashchuk Sergii}

study; helps to identify the links between scientific knowledge and life, theory and practice; facilitates educational and cognitive activity and promotes the formation of interests in professional knowledge; helps to comprehensively comprehend the subject being studied» [20, p. 18-19].

The principle of the unity of theoretical and practical training is based on the fact that any theoretical position should be confirmed and verified in practice; the practical results obtained should have a theoretical explanation. That is, in the educational process of developing the professional-legal competence practical training in parallel with theoretical material should occupy a proper place in future social workers. It is this combination that will enable future professionals to be fully self-assured in their professional life. «Lifelong learning», where traditional skills (computer work, foreign languages, technological culture and ingenuity) are supplemented with the ability to learn throughout life, work with information, critically rethink it, according to N. Ortikova [21, p. 183-188], puts forward the new tasks in the system of vocational education and directs their solution with an emphasis on a wide range of applications of advanced methods, forms and techniques.

Construction of the educational process taking into account the aforementioned theoretical and practical pedagogical conditions [22, p. 102-106] and on the basis of the system of the above-mentioned generaledacity and specific (accounting and development of training motivation, integrity, consistency or systematicity, integrity) of scientific principles $[10$, p. 232-242] determines the successful development of professional competence in future social workers in higher education institutions.

Among the specific scientific principles, we highlight the following: the consideration and development of the motivation of learning during the students' activity (activating cognitive activity), which enables students to independently choose the forms of activity in classroom and non-auditorium conditions under the direct supervision of teachers or indirectly under their influence; the principle of integrity, which involves the disclosure by students of professional activity as a holistic phenomenon; systematic due to the character of modern education: through system of developing the professional-legal competence (when studying professionally oriented and special disciplines, introduction of an elective, vocational guidance activities); the complexity caused by the necessity to involve a complex of educational disciplines in the development of the professional-legal competence of future social educators. 


\section{Chapter «Pedagogical sciences»}

As the professional-legal competence of future social workers is a complicated systemic phenomenon, to monitor the state of its development at various stages of pedagogical research (statement, forming), selection of pedagogical and psychological methods of diagnosis of motivationalvalue, practical-activity, cognitive, person-reflexive components of the professional competence of future social workers, which became the basis for determining the relevant indicators formed the level of professional competence of future social workers, the criteria (depth, completeness and strength of professional legal knowledge, the quality of developing the professional skills, formation of values of professional-legal orientations, strength and stability of professional-legal motives) and levels (low (empirically-intuitive), satisfactory (reproductive), sufficient (functional), high (reflexive-creative)) formation of the professional competence of future social workers who are in digital equivalents respectively, have indicators of 2, 3, 4 and 5 points.

\section{Conclusions}

For developing the professional competence of future social workers, we suggest using a set of traditional and innovative forms and methods: work in small groups: social and legal training, social and legal projects, social and legal cases, intellectual and legal games, social and legal problems; frontal work: lecture-situation; mini lecture, brainstorming.

A methodology of professional and legal competence formation of prospective social workers in higher educational institutions has been introduced and verified experimentally. It is implemented through introduction into educational process: an online elective course on Professional and Legal Culture of Social Worker; methodological recommendations for teaching and academic staff on Professional and Legal Competence Development of Prospective Social Workers; methodological recommendations for students on Techniques of Professional and Legal Self-Education, Respect for the Rights of Students with Special Needs: Foreign Experience.

The study does not exhaust all aspects of the problem of forming the professional competence of future social workers. Further development requires the development of professional competence of future social workers in the conditions of distance learning organization and formation of teachers' readiness for innovation in the system of postgraduate education. 


\section{Kovalchuk Vasyl, Zhuravska Nina, Yashchuk Sergii}

\section{References:}

1. Kovalchuk V. I. (2016). Tendentsii rozvytku osvitnoi systemy v Ukraini [Trends in the development of the educational system in Ukraine]. Economics, science, education: integration and synergy. Materials of international scientific and practical conference, 18-21 January 2016. Kyiv: Tsentr navchalnoi literatury, 2016, pp. 79-80.

2. Kovalchuk V. I. (2016). Rozvytok vyshchoi osvity vidpovidno do tendentsii i vymoh rynku pratsi [Development of higher education in accordance with the trends and requirements of the labor market]. Rozvytok suchasnoi osvity: teoriia, praktyka, innovatsii. Materialy II Mizhnarodnoi naukovo-praktychnoi konferentsii, 25-26 liutoho 2016 roku. Kyiv: «Milenium», pp. 22-24.

3. Kovalchuk V. (2016) High education system challenges in the context of requirements of labour market and society. Scientiic letters of academic society of Michal Baludansky, pp. 88-90.

4. Kovalchuk V. I. (2015). Tendentsii innovatsiinoho rozvytku suchasnoi shkoly v Ukraini [Trend of innovative development of a modern school in Ukraine]. Imidzh suchasnoho pedahoha, № 7, pp. 3-6.

5. Malykhin O. V., Kovalchuk V.I., Aristova N. O., Popov R. A., Hrytsenko I. S. (2017). Tendentsii rozvytku osvity $\mathrm{v}$ epokhu informatsiinoho suspilstva [Trends in the development of education in the era of information society]. Stratehii intensyfikatsii vyshchoi humanitarnoi osvity v Ukraini ta krainakh YeS: monohrafiia [Strategies for the intensification of higher humanitarian education in Ukraine and EU countries: monograph]. Kyiv: NUBiP Ukrainy, 2017, pp. 7-134.

6. Zhuravska N.S. (2016). Suchasni tendentsii v sferi trudovoi mihratsii: problemy ta zavdannia dlia vyshchoi osvity [Contemporary trends in labor migration: challenges and challenges for higher education]. Naukovyi visnyk Natsionalnoho universytetu bioresursiv i pryrodokorystuvannia Ukrainy. Kyiv, № 253, pp. 53-57.

7. Andrushchenko V., Divinska N., Korolov B. (2008). Osobystisno oriientovani tekhnolohii navchannia i vykhovannia u vyshchykh navchalnykh zakladakh: kolektyvna monohrafiia [Personally oriented technologies of education and upbringing in higher educational institutions: collective monograph]. Kyiv: Ped. dumka, 2008, pp. 227-245.

8. Koval L., Zvereva I., Khlebyk S. (1997). Sotsialna pedahohika. Sotsialna robota: navchalnyi posibnyk [Social pedagogy. Social work: tutorial]. Kyiv: IZMN, 392 p.

9. Asotsiatsiia sotsialnykh pratsivnykiv SShA [American Social Workers Association]. Retrieved from: www.socialworkers.org (accessed 26 January 2018).

10. Naukovi zapysky. Ser.: Pedahohichni ta istorychni nauky: zb. nauk. st. Kyiv: Nats. ped. un-t imeni M. P. Drahomanova, 2013. Vyp. CIX. № 109, 299 p.

11. Pro Stratehiiu staloho rozvytku «Ukraina - 2020»: Ukaz Prezydenta Ukrainy vid 12.01.2015 № 5/2015 [About the Strategy of Sustainable Development «Ukraine 2020»: Decree of the President of Ukraine dated January 12, 2015 № 5/2015]. Retrieved from: http://zakon3.rada.gov.ua/laws/show/5/2015\#n10 (accessed 10 February 2019).

12. Glavnaya problema $\mathrm{v}$ sfere sotsialnogo obespecheniya uchastnikov ATO nedostatochnaya informirovannost (2015). [The main problem in the field of social security of participants of the ATO - lack of awareness]. Donbass informatsionnyy - 


\section{Chapter «Pedagogical sciences»}

putevoditel po Donetskoy oblasti. Retrieved from: http://www.donbass-info.com/ content/view/23730/23741 (accessed 14 May 2015).

13. Yashchuk S. P. (2018). Pedahohichni umovy formuvannia profesiinopravovoi kompetentnosti maibutnikh sotsialnykh pratsivnykiv [Educational Environment for Professional and Legal Competence Formation of Prospective Social Workers (PhD Thesis). Rivne, $23 \mathrm{p}$.

14. Yashchuk S. P. (2018). Pedahohichni umovy formuvannia profesiinopravovoi kompetentnosti maibutnikh sotsialnykh pratsivnykiv [Educational Environment for Professional and Legal Competence Formation of Prospective Social Workers. Dys. kand. ped. nauk: 13.00.04. Rivne, 2018, 301 p.

15. Yashchuk S. P. (2016). Problemno-rozvyvalne navchannia yak zasib rozvytku profesiino-pravovoi kompetentnosti studentiv [Problem-developmental knowledge of the development of legal competence of students]. Visnyk Zhytomyrskoho derzhavnoho universytetu imeni Ivana Franka. Ser.: Pedahohichni nauky. Vyp. 4(86). S. 175-179.

16. Zakon Ukrainy «Pro vyshchu osvitu» № 1556-VII [The Law of Ukraine «About higher education»]. Retrieved from: http://zakon5.rada.gov.ua/laws/ show/1556-18 (accessed 12 January 2016).

17. Yashchuk S. P. (2017). Vdoskonalennia profesiinoi pidhotovky maibutnikh sotsialnykh pratsivnykiv: orhanizatsiia eksperymentalnoho doslidzhennia. [Awareness of the professional preparation of the Maybut social societies: Organizational Experimental Training]. Innowacje $i$ nowoczesne technologie $w$ edukacji: wkład Polski i Ukrainy. (Sandomierz, 5-6 may 2017). Sandomierz, Polska. P. 43-48.

18. Kurliand Z. N., Khmeliuk R. I., Semenova A. V. (2007). Pedahohika vyshchoi shkoly: navch. posib. [High school pedagogy: tutorial]. Kyiv: Znannia, 495 p.

19. Pidkasistyy P. I. (1996). Pedagogika [Pedagogy]. Moskva: Rossiyskoe pedagogicheskoe obshchestvo, $602 \mathrm{p}$.

20. Pometun O., Pirozhenko L. (2004). Suchasnyi urok. Interaktyvni tekhnolohii navchannia: nauk.-metod. posib. [Contemporary lesson. Interactive Learning Technologies: tutorial]. Kyiv: A.S.K., 192 p.

21. Pedahohichnyi protses: teoriia i praktyka (2005). [Pedagogical Process: Theory and Practice]. VAK Ukrainy; Instytut pedah. i psykhol. prof. osvity APN Ukrainy. Kyiv. Vyp. 3. 297 p.

22. Yashchuk S. P. (2016). Formuvannia profesiino-pravovoi kompetentnosti maibutnikh sotsialnykh pratsivnykiv: metodyka orhanizatsii ta provedennia eksperymentalnykh doslidzhen [Formation of professional competence of future social workers: a methodology for organizing and conducting experimental research.]. Osvitni innovatsii: filosofiia, psykholohiia, pedahohika: materialy III mizhnar. nauk.prakt. konf. (Sumy, 8 hrudnia 2016 r.). Sumy, 2016. Ch. 2, pp. 102-106. 